\title{
Persepsi Guru tentang Proses Supervisi oleh Kepala Sekolah di SMKN 2 Bukittinggi
}

\author{
Nindi Elissa ${ }^{1}$, Sulastri Sulastri ${ }^{2}$, Ermita $^{3}$, Lusi Susanti $^{4}$ \\ ${ }^{1}$ Administrasi Pendidikan, UniversitasNegeri Padang 1, ${ }^{2}$ AdministrasiPendidikan, UniversitasNegeri Padang 2, \\ ${ }^{3}$ AdministrasiPendidikan, UniversitasNegeri Padang 3, ${ }^{4}$ AdministrasiPendidikan, UniversitasNegeriPadang 4
}

Nindi Elissa ${ }^{1}$, e-mail: nindielissa98@gmail.com

Sulastri² e-mail:sulastri_aip@fip.unp.ac.id

Ermita3 e-mail:ernitarustam1114@gmail.com

Lusi Susanti ${ }^{4}$ e-mail:lusy_mp@yahoo.com

\begin{abstract}
This research is based on the result of the author's observation of the supervision process which in its implementation is still not running effectively in SMK Negeri 2 Bukittinggi. The purpose of this research is to obtain data on the teacher's view on supervision activities seen in the following indicators: supervision planning, supervision implementation, supervision evaluation and follow-up supervision results. This research uses descriptive research using quantitative methods. The population in this study was all civing servant teachers in SMK Negeri 2 Bukittinggi which amounted to 80 people, and the amount of samples taken from respondents was 74 people. The sample withdrawal in this study uses proportional stratified random sampling technique. The data obtained has been tested for validity and reliability. The average formulation is used in processing data in this study. The data showed the teacher's view of supervision activities: (1) planning scored with an average of 4,28 good categories; (2) implementation of getting a score with an average of 4,35 good average (3) evaluation gets a score with an average of 4,34 good category; (4) follow-up result get a score with a good category average of 4,33. The results obtained in this study were about the teacher's view of the process of obtaining a score with an average of 4,33 good categories. The data obtained has been tested for validity and reliability. The average formulation is used in processing data in this study.
\end{abstract}

\begin{abstract}
Abstrak
Penelitian ini didasarkan oleh hasil pengamatan penulis mengenai proses supervisi yang dalam pelaksanaannya masih kurang berjalan dengan efektif di SMK Negeri 2 Bukittinggi. Tujuan dalam penelitian ini yaitu untuk memperoleh data tentang pandangan guru mengenai kegiatan supervisi dilihat dalam indikator-indikator sebagai berikut: perencanaan supervisi, pelaksanaan supervisi, evaluasi supervisi dan tindak lanjut hasil supervisi. Penelitian ini menggunakan jenis penelitian deskriptif dengan menggunakan metode kuantitatif. Populasi pada penelitian ini yaitu seluruh guru PNS yang ada di SMK Negeri 2 Bukittinggi yang berjumlah 80 orang, dan besarnya sampel yang diambil dari responden adalah 74 orang. Penarikan sampel pada penelitian ini memakai teknik Proportional Stratified Random Sampling. Data yang diperoleh sudah diuji validitas dan reliabilitasnya. Rumusan rata-rata digunakan dalam mengolah data pada penelitian ini. Data menunjukkan pandangan guru mengenai kegiatan supervisi: (1) perencanaan mendapatkan skor dengan rata-rata 4,28 berkategori baik; (2) pelaksanaan mendapatkan skor dengan rata-rata 4,35 berkategori baik; (3) evaluasi mendapatkan skor dengan rata-rata 4,34 berkategori baik; (4) tindak lanjut hasil mendapatkan skor dengan rata-rata 4,3 berkategori baik. Hasil yang didapatkan pada penelitian ini tentang pandangan guru terhadap proses memperoleh skor dengan rata-rata 4,33 berkategori baik.
\end{abstract}

Kata Kunci:Persepsi, proses supervisi kepala sekolah

How to Cite: Nindi Elissa1, Sulastri Sulastri 2, Ermita 3, Lusi Susanti 4, 2021.Persepsi Guru tentang Proses Supervisi oleh Kepala Sekolah di SMKNegeri 2 Bukittinggi. Journal Educational Administrasi and Leadership, Vol (N): pp.XX-XX,DOI:10.24036/XXXXXXXXXX-X-XX 


\section{Pendahuluan}

(Arikunto Suharsimi, 2006) menjelaskan bahwa supervisi adalah semua kegiatan yang terjadi dalam supervisi ketika supervisi sedang berlangsung. Menurut (Sahertian, 2008) mengemukakan bahwa fungsi utama dari supervisi tidak sekedar berfokus pada perbaikan proses pembelajaran saja tetapi untuk mengkoordinasi, menstimulasi, dan mendorong ke arah pertumbuhan profesi guru.

Seorang guru harus mampu merencanakan kegiatan untuk kelasnya dan memilih pengalaman belajar yang efektif. Seorang guru yang profesional harus digalang secara sistematis melalui kegiatan pembinaan profesional guru melalui pengawasan yang dilakukan kepala sekolah. (Mulyasa, 2012) mengemukakan bahwa tugas seorang kepala sekolah sebagai pengawas yaitu melakukan pengawasan terhadap kegiatan pembelajaran yang dilakukan oleh guru.

Indikator yang digunakan kepala sekolah dalam supervisi yaitu:

a. Perencanaan supervisi mencakup beberapa hal diantaranya tujuan dilakukannya supervisi, alasan pelaksanaan, kapan dilakukannya, metode yang dipakai, dan subjek yang terkait supervisi tersebut (Muhammad, 2000)

b. Pelaksanaan supervisi terdiri dari beberapa macam kegiatan yaitu, mengumpulkan data, melakukan penilaian, mencari tahu kelemahan, melakukan perbaikan, melakukan penyuluhan (Rifa'i Moh, 1991)

c. Evaluasi supervisi, aspek yang harus dievaluasi yaitu evaluasi aspek hasil, evaluasi aspek pelaksana, Muhammad (2000)

d. Tindak lanjut hasil supervisi dapat menggunakan cara yaitu, memberikan feedback kepada guru berdasarkan hasil supervisi, mendorong guru untuk mempertimbangkan alternatif tujuan pembelajaran, metode dan alasan, memberi guru kesempatan untuk melakukan praktek dan perbandingan (Wijono, 1989)

Permasalahan yang penulis amati dan dilihat di lapangan ialah kurang terlaksananya proses supervisi dengan baik. Masih belum maksimalnya kepala sekolah dalam melakukan supervisi, terlihat dari bantuan dan pembinaan oleh kepala sekolah yang dilakukan kepada guru selaku seorang pengawas, contohnya dalam pembuatan RPP, masih belum berjalan dengan baik kegiatan supervisi yang dilakukan, dalam melaksanakan pembelajaran masih kurang maksimalnya pengawasan dan bimbingan dari kepala sekolah terhadap guru, kepala sekolah, masih kurang tepat dalam memakai teknik supervisi, dalam menindaklanjuti hasil supervisi kepala sekolah kurang melibatkan guru.

Berdasarkan pemaparan diatas maka yang akan diteliti yaitu: : 1) bagaimanakah pandangan guru mengenai kegiatan supervisi dalam hal perencanaan supervisi? 2) bagaimanakah pandangan guru mengenai kegiatan supervisi dalam hal pelaksanaan supervisi? 3) bagaimanakah pandangan guru mengenai kegiatan supervisi dalam hal evaluasi supervisi? 4) bagaimanakah pandangan guru mengenai kegiatan supervisi dalam hal tindak lanjut supervisi?

\section{Metode Penelitian}

Tempat yang dilakukan oleh peneliti ialah SMKN 2 Bukittinggi. Jenis riset ialah kuantitatif.Guru PNS SMKN 2 Bukittinggi yang berjumlah 80 orang yang dijadikan populasinya 74 responden dengan memakai metode proportional stratified random sampling.penelitian ini memakai angket dengan skala likert yang telah dilakukan uji validitas dan reliabilitas, rumus rata-rata yang dilakukan untuk memperoleh data hasil penelitian.

\section{Hasil dan Bahasan}

\subsection{Hasil}

Berdasarkan penelitian berikut dijelaskan satu persatu menurut indikator peneliti:

Secara keseluruhan skor rata-rata tentang pandangan guru mengenai kegiatan supervisi dilihat dalam hal: a) perencanaan supervisi adalah 4,28 berkategori baik, hal ini diartikan bahwa perencanaan supervisi telah terlaksana dengan baik dan hanya perlu untuk ditingkatkan. b) pelaksanaan supervisi adalah 4,35 berkategori baik, hal ini dikatakan bahwa pelaksanaan supervisi sudah terlaksana dengan baik dan hanya perlu ditingkatkan. c) evaluasi supervisi adalah 4,34 berkategori baik, hal ini dikatakan bahwa pelaksanaan evaluasi sudah terlaksana dengan baik dan hanya perlu ditingkatkan. d) tindak lanjut hasil supervisi adalah 4,33 berkategori baik, hal ini dikatakan bahwa pelaksanaan tindak lanjut hasil supervisi terlaksana dengan baik dan hanya perlu ditingkatkan.

\subsection{Pembahasan}


Berdasarkan hasil dari penelitian pandangan guru mengenai kegiatan supervisi dari kepala sekolah di SMK Negeri 2 Bukittinggi dilihat dalam hal perencanaan pada taraf baik dengan rata-rata 4,28. Pelaksanaan pada taraf baik dengan memperoleh skor rata-rata 4,35. Evaluasi mendapatkan skor rata-rata 4,34 pada taraf baik, Tindak lanjut hasil pada taraf baik dengan memperoleh skor rata-rata 4,33.

a.Perencanaan

Hasil pengolahan data penelitian menunjukkan bahwa dilihat dalam hal perencanaan supervisi mendapatkan rata-rata 4,28 dengan kategori baik. Dengan 14 item pernyataan. Dilihat dari segi perencanaan yang tertinggi yaitu terdapat pada pernyataan "kepala sekolah menjelaskan kepada guru rangkaian kegiatan yang akan dilaksanakan" dengan skor rata-rata 4,49. Berarti telah dilakukan dengan baik. Sedangkan item yang terendah pada pernyataan "kepala sekolah menganalisis ancaman yang mungkin disebabkan oleh guru" mendapatkan skor rata-rata 4,2. Artinya dapat diamati dari aspek perencanaan telah tercapai dengan baik.

b.Pelaksanaan

Pengolahan hasil data penelitian menunjukkan bahwa dilihat dalam hal pelaksanaan mendapatkan rata-rata 4,35 dengan kategori baik. Dengan 14 item pernyataan. Dilihat dari segi pelaksanaan yang tertinggi yaitu terdapat pada pernyataan "kepala sekolah mengumpulkan capaian belajar siswa untuk melihat kemampuan guru dalam mengajar." dengan skor rata-rata 4,51. Berarti telah dilakukan dengan baik. Sedangkan item terendah terdapat pada pernyataan " pada saat proses pembelajaran berlangsung kepala sekolah memperhatikan guru untuk melihat penguasaan materi." mendapatkan skor rata-rata 4,15. Artinya dapat diamati dari aspek pelaksanaan telah tercapai dengan baik.

c.Evaluasi

Pengolahan hasil data penelitian menunjukkan bahwa dilihat dalam hal evaluasi mendapatkan ratarata 4,34 dengan kategori baik. Dengan 14 item pernyataan. Dilihat dari segi evaluasi yang tertinggi yaitu terdapat pada pernyataan "kepala sekolah melakukan evaluasi hasil supervisi secara individual" dengan skor rata-rata 4,47. Berarti telah dilakukan dengan baik. Sedangkan item terendah terdapat pada pernyataan " kepala sekolah mengevaluasi peningkatan kemampuan guru dalam melaksanakan pembelajaran setelah pelaksanaan supervisi" memperoleh skor rata-rata 4,3. Artinya dapat diamati dari aspek evaluasi telah tercapai dengan baik.

d.Tindak lanjut hasil

Pengolahan hasil data penelitian menunjukkan bahwa dilihat dalam hal tindak lanjut hasil mendapatkan rata-rata 4,33 dengan kategori baik. Dengan 13 item pernyataan. Dilihat dari segi tindak lanjut hasil yang tertinggi yaitu terdapat pada pernyataan " guru yang masih memiliki hambatan dalam mengajar diberikan bimbingan secara individu oleh kepala sekolah untuk perbaikan lebih baik." mendapatkan skor rata-rata 4,49. Berarti telah dilakukan dengan baik. Sedangkan item terendah terdapat pada pernyataan "kepala sekolah bersama dengan guru menganalisis hasil supervisi yang telah dicapai" mendapatkan skor rata-rata 4,2. Artinya dapat diamati dari aspek tindak lanjut hasil supervisi sudah terlaksana dengan baik.

\section{Kesimpulan}

Kesimpulan hasil dari penelitian mengenai pandangan guru mengenai kegiatan supervisi dilihat dalam hal perencanaan menghasilkan skor dengan rata-rata 4,28 tercatat dalam golongan baik. Pelaksanaan mendapatkan skor rata-rata 4,35 termasuk dalam kategori baik. Evaluasi menghasilkan skor dengan rata-rata 4,34 tercatat dalam golongan baik. Tindak lanjut hasil mendapatkan skor dengan rata-rata 4,33 tercatat dalam golongan baik. Secara umum pandangan guru mengenai kegiatan supervisi mendapat skor dengan rata-rata 4,33 yang tercatat dalam golongan baik.

Berdasarkan kesimpulan diatas, tentang pandangan guru mengenai kegiatan supervisi bisa dikatakan sudah terlaksana dengan baik sesuai dengan angket yang diisi oleh guru, untuk itu masih perlu adanya peningkatan dalam proses supervisi kepala sekolah untuk mencapai tingkat kategori sangat baik, agar proses supervisi oleh kepala sekolah dapat terlaksana dengan lebih optimal dan hasilnya sesuai dengan tujuan dari supervisi.

\section{Daftar Rujukan}

Arikunto Suharsimi. (2006). Dasar-dasar supervisi. Asdi Mahasatya. 
Nindi Elissa ${ }^{1}$, Sulastri Sulastri ${ }^{2}$, Ermita $^{3}$, Lusi Susanti ${ }^{4}$ Persepsi Guru tentang Proses Supervisi oleh Kepala Sekolah di SMKNegeri 2 Bukittinggi.

Muhammad. (2000). Supervisi Pendidikan. Fip Universitas Negeri Padang.

Mulyasa. (2012). Manajemen dan Kepemimpinan Kepala Sekolah. Bumi Aksara.

Rifa’i Moh. (1991). Administrasi dan Supervisi Pendidikan. Bumi Aksara.

Sahertian, P. A. (2008). Konsep Dasar \& Teknik Supervisi Pendidikan Dalam Rangka Pengembangan Sumber Daya Manusia. Rineka Jaya.

Wijono. (1989). Administrasi Dan Supervisi Pendidikan. Dirjen Dikti. 
JOURNAL OF EDUCATIONAL ADMINISTRATION AND LEADERSHIP

Volume 2 Nomor 2 Tahun 2021, Hal 197-201

ISSN: Print 2745-9691- Online 2745-9683

DOI: https://doi.org/10.24036/jeal.v2i2

Diterima Redaksi : 30-11-2021 | Selesai Revisi : 15-12--2021| Diterbitkan Online : 28-12--2021 